\title{
An unexpected patron: A social-scientific and realistic reading of the parable of the Vineyard Labourers (Mt 20:1-15)
}

\begin{tabular}{|c|c|}
\hline \multicolumn{2}{|c|}{$\begin{array}{l}\text { Authors: } \\
\text { Ernest van Eck }{ }^{1} \\
\text { John S. Kloppenborg }\end{array}$} \\
\hline $\begin{array}{l}\text { Affiliations: } \\
{ }^{1} \text { Department } \\
\text { Testament Stu } \\
\text { of Theology, } \\
\text { Pretoria, Sout }\end{array}$ & $\begin{array}{l}\text { f New } \\
\text { dies Faculty } \\
\text { niversity of } \\
\text { h Africa }\end{array}$ \\
\hline $\begin{array}{l}{ }^{2} \text { Department } \\
\text { of Religion, Ur } \\
\text { Toronto, Cana }\end{array}$ & $\begin{array}{l}\text { or the Study } \\
\text { niversity of } \\
\text { da }\end{array}$ \\
\hline $\begin{array}{l}\text { Corresponder } \\
\text { Ernest van Eck }\end{array}$ & ce to: \\
\hline $\begin{array}{l}\text { Email: } \\
\text { ernest.vaneck }\end{array}$ & @up.ac.za \\
\hline $\begin{array}{l}\text { Postal addres } \\
\text { Private Bag X2 } \\
0028, \text { Univers } \\
\text { South Africa }\end{array}$ & $\begin{array}{l}0, \text { Hatfield } \\
\text { ity of Pretoria, }\end{array}$ \\
\hline $\begin{array}{l}\text { Dates: } \\
\text { Received: } 03 \mathrm{~J} \\
\text { Accepted: } 02 \\
\text { Published: } 08\end{array}$ & $\begin{array}{l}\text { an. } 2015 \\
\text { Feb. } 2015 \\
\text { May } 2015\end{array}$ \\
\hline $\begin{array}{l}\text { How to cite th } \\
\text { Van Eck, E. \& } \\
\text { J.S., 2015, 'An } \\
\text { patron: A soci } \\
\text { and realistic r } \\
\text { parable of the } \\
\text { Labourers (Mt } \\
\text { HTS Teologies } \\
\text { Theological St } \\
\text { Art. \#2883, } 11 \\
\text { dx.doi.org/10. } \\
\text { v71i1.2883 }\end{array}$ & $\begin{array}{l}\text { is article: } \\
\text { Kloppenborg, } \\
\text { unexpected } \\
\text { al-scientific } \\
\text { eading of the } \\
\text { Vineyard } \\
\text { 20:1-15)', } \\
\text { e Studies/ } \\
\text { udies 71(1), } \\
\text { pages. http:// } \\
4102 / \text { hts. }\end{array}$ \\
\hline $\begin{array}{l}\text { Copyright: } \\
\text { (C) 2015. The A } \\
\text { Licensee: AOS } \\
\text { OpenJournals } \\
\text { licensed unde } \\
\text { Commons Attr } \\
\text { License. }\end{array}$ & $\begin{array}{l}\text { uthors. } \\
\text { IS } \\
\text { This work is } \\
r \text { the Creative } \\
\text { ibution }\end{array}$ \\
\hline 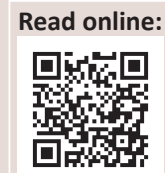 & $\begin{array}{l}\text { Scan this QR } \\
\text { code with your } \\
\text { smart phone or } \\
\text { mobile device } \\
\text { to read online. }\end{array}$ \\
\hline
\end{tabular}

Many readings of the Parable of the Labourers in the vineyard want to treat the owner as representing God. Knowledge of actual agricultural practices relating to the management of vineyards suggest, on the contrary, that the details of the parable obstruct an easy identification of the owner with God, and that he displays unusual behaviour not only by paying all the labourers the same wage, but by his very intervention in the hiring process. The conclusion reached is that the parable constructs the vineyard owner, typically one of the nouveau riche who lived in cities, not only as a 'good employer' but also, contrary to expectation, as a patron who intervened well beyond the strict norms of economic exchange.

\section{Introduction}

The interpretation of the Vineyard Labourers has in the past hinged on several decisions: Since the owner has a manager, should his face-to-face hiring of workers at the marketplace be interpreted as normal or abnormal? Who are the workers being hired? Why does the owner not agree with those being hired later on a specific wage? Why does the owner hire workers up to five o'clock? Why are the workers paid in a reversed order? Is the owner in the parable a symbol for God, and does the vineyard represent Israel? And finally, should the actions of the owner in the parable be interpreted as negative or positive? Is he depicted as a positive or a negative figure?

While in the past, interpreters have tried to answer these questions without paying much attention to actual agricultural practices in antiquity, and hence debate whether, for example, the owner is a figure for God or a villainous exploiter of the poor, this article attends closely to social and economic practices in the agricultural sector of the Roman economy in order to assess the degree of realism of specific details of the parable, and the points at which the narrator deliberately confronts audience expectations with what is 'normal' about a narrative artifice that produces a surprising outcome. In the interpretive tradition since C.H. Dodd, this article argues that parables trade in realistic scenarios from Palestinian life, but depict figures in those stories as acting in odd ways, in this case, as an unexpected patron of his agricultural workers.

\section{History of interpretation}

Most of the earliest interpreters of the parable, as expected, have immediately allegorised the parable. ${ }^{1}$ The earliest allegorisation of the parable is that of Matthew: By placing the parable between Matthew 19:30 and 20:16 (the last-first and first-last revision of positions), Matthew anticipates the request of the mother of the sons of Zebedee in Matthew 20:20-21 and Jesus' response in Matthew 20:26-28; the first are those who slave for the benefit of other. For Matthew, the parable thus has as its focus discipleship (Snodgrass 2008:375). The parable is intended 'to exclude arrogance, ideas of superiority over others in the kingdom, and any idea that God's assessment is to be understood by some kind of reckoning. ${ }^{2}$

Another popular allegorical reading amongst interpreters of the parable is to equate the early workers with the 'Jews', and those who started working later, with the 'Gentiles'. With this as cue, the grumbling of the first workers are interpreted as a judgement of the 'Gentiles' based on

1.See Tevel (1992). Origen's allegorical interpretation of the parable is well known. In his reading the five hirings represent the five periods from Adam to Noah (Origen, Comm. in Matt. 15:33-34 [Klostermann, GCS 10,447-448]), whilst others see in the five hirings the five senses or the five stages in life at which people experience conversion (see Wailes 1987:137-144). Some modern interpreters also read the parable allegorically: Culbertson (1988:262) sees the vineyard as a symbol for Israel, and for Stern (2006:102-14) the wages received represent the gift of eternal life. Linked to this interpretation, Blomberg $(2012: 282,285)$ argues that the parable shows that there are no degrees of reward in heaven; all the workers hired are God's true people, and all are rewarded equally. Trench (1877:151), finally, identifies divine election in the parable: many are called to God's vineyard, but few retain the humility which will
allow them in the end to be partakers of God's salvation.

2.See also Davies and Allison (1997:333), Elliott, (1992:52-65), Blomberg (2012:222), Kistemaker (1980:74), Hagner (1995:572) and Cowan (2007:47-59). 
salvation by works (see, e.g., Drury 1985:92-95; Lambrecht 1992:84; Hagner 1995:574; Patte 1999:96).

An allegorical-theological reading of the parable is also common amongst a large number of interpreters. In this reading the owner of the vineyard is seen as a symbol of God. With this as lens, the focus of the parable is interpreted as an example of God's grace (Bultmann 1968:190; Jones 1995:42; Ball 2000:124; Young 1998:69; Hultgren 2000:35; Stiller 2005:59; Hunter 1976:52; Fisher 1990:88) or justice (Buttrick 1928:163), or a short narrative teaching that salvation is gained by grace alone (Bornkamm 1960:142; Jülicher 1910; Oesterley 1936:109-110; Via 1967:155).

Scholars who are interested in the original setting in which the parable was told in most cases follow the interpretation of Jeremias $(1972: 38,139)$. According to Jeremias, the original setting of the parable was the public criticism of the Pharisees (represented by the murmurers in Mt 20:11-12) of Jesus' eating with tax collectors and sinners. The parable, he argues, was Jesus' defence against these criticisms to show how 'unjustified, hateful, loveless and unmerciful' their criticism of him is (Jeremias 1972:139). God is merciful, and even has place for the tax collectors and sinners in the kingdom. Interestingly, in these interpretations the owner is also seen as a reference to God. ${ }^{3}$

Not all scholars who are interested in reading the parable in the context of the historical Jesus (27-30 CE), however, follow Jeremias's interpretation. Scholars like Scott, Herzog, Levine and Myrick, Borg, Bailey, Crossan, Vearncombe and Shillington read the parable against the socio-economic realities of 1st-century Palestine, depicting the owner of the vineyard as either a negative or positive symbol.

According to Herzog (1994:97), the parable codifies the oppression of the peasantry by wealthy landowners in the time of Jesus. Jesus told the parable, to expose the contradiction between the actual situation of the hearers of the parable and God's justice. This is also the point of view of Borg and Crossan. The parable, in Borg's (2006:181-183) interpretation, raises consciousness about the domination system in Jesus' time. Crossan's (2012:98) reading follows a similar line: The parable focuses on the idleness of the workers, intending to raise the audience's consciousness about the distinction between personal justice and injustice (the owner), and systemic justice and injustice (the economy). The obvious difficulty with these kinds of interpretations is that they presuppose post-Enlightenment analyses and conceptual frameworks. It is well known that the concept of economy - that is, a conception of macro-structural systems of exchange - was not part of ancient thinking. Oikonomia was, as the name suggests, 'household management'. Likewise, the notion of 'domination' presupposes postMarxist analyses of modes of production, ideology, and class, none of which existed as discourses in antiquity. One does find criticism of people who were regarded as wealthy, arrogant, abusive, unjust and the like, but systemic critiques are absent because the conceptual frameworks to support such critiques were yet to be invented.

Shillington (1997:98-101) sees the owner as a positive symbol. By paying all the workers the same wage, he argues, the owner enables all the workers to keep the Sabbath; because all were paid the expected daily wage, all could celebrate their achievements during the week and could rest from their labour on the Sabbath to follow. Bailey (2008:355) also sees the owner of the vineyard as a positive symbol; the focus of the parable is the owner's amazing compassion and sensitivity for the unemployed.

Scott (1989:289, 294), in employing a social-scientific approach, reads the parable through the lens of patronage and clientism. The hiring of the labourers, in his opinion, sets up a patron-client relationship. By paying all the workers the same wage, the owner in essence makes them all equal, and by doing this, destroys the order of the world and breaks up the Roman patron-client system that dominated the world of the exploited in 1st-century Palestine (Scott 2007:111-112). For Scott, the owner thus also functions as a positive symbol in the parable.

Levine and Myrick (2013:95-115), finally, argue that the parable 'teaches a lesson about creating equality among ... workers' (Levine \& Myrick 2013:109). Jesus speaks in the parable to some who do not recognise their responsibility to people with less (Levine \& Myrick 2013:99), and in telling the parable, Jesus "'encouraged landowners" to enact the graciousness of God by "speaking of a vineyard owner who generously assisted some impoverished day laborers"' (Levine \& Myrick 2013:112, cited in following Capper). Understood from this perspective, the owner in the parable is a role model for the rich; the rich should 'continue to call others to the field; pay equally and generously' (Levine \& Myrick 2013:112). In this reading the owner of the vineyard is thus also a positive symbol (contra Herzog), with the first workers being the tyrants and exploiters who do not want the last hired to have a living wage (Levine \& Myrick 2013:110).

Perhaps the most sophisticated analysis to date, Vearncombe (2010), after examining the particulars of viticulture in the 1st century, the status of غ́pyó $\alpha \alpha$ vis à vis other agricultural workers, and the expectations in an agrarian culture of balanced reciprocity, concludes that:

$[I] \mathrm{n}$ a socio-economic setting characterized by extreme asymmetry and valuing self-interest, the householder creates a new social bond in the giving of a 'gift', however small it may be, to the labourers. The parable may consequently be interpreted as follows: the kingdom of heaven represents a reversal of the world's values. It is like someone who acts contrary to the general concern for profit and self-interest in demonstrating a certain reciprocal solidarity with persons of a much lower social status. (p. 235)

4.Citing Oakman (1986:165): "Generosity undercuts the prevailing order established on the assumption of a quid pro quo and a self-sufficient household economy.' 
Below we will challenge the common assumption that the owner in the parable is a place holder for God, despite the fact that this is the way that Matthew wishes to construe the parable. The owners of vineyards were not typically drawn from social ranks that inspired admiration. Nevertheless, the parable does trade in some generally realistic representations of viticulture in 1st century Jewish Palestine, and invokes cultural scripts shared by its hearers but at critical points interrupts those scripts. A knowledge of the realities of ancient viticulture will enable the interpreter of the parable to identify the surprising narrative turns in the parable. Fundamental to the social world invoked by the parable is the ambivalence between two models of social and economic exchange - the strict quid pro quo exchange of the labour market, and the balanced reciprocity of the practice of patronage. In its use of narrative artifice, the parable constructs the unusual actions of the owner as a patron, someone who emulates what it means to be díkalos. But first a comment on the integrity of the parable.

\section{Integrity}

There is almost unanimity amongst scholars regarding the integrity of the parable, arguing that Matthew 20:16 is a redactional addition of Matthew. ${ }^{5}$ As noted earlier, Matthew most probably added Matthew 20:16 to echo Matthew 19:30, and, linking these two verses with Matthew 20:8b, applied the parable received from the tradition to focus on discipleship. The saying in Matthew 20:16 and 19:30 (in reversed order) most probably is derived from Q 13:30 (oî

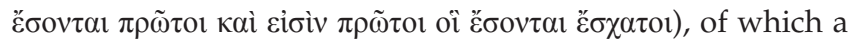
shorter version also occurs in Gospel of Thomas 4.2 (see also Mk 9:35; Lk 14:9). Interestingly Chrysostom, as early as in the 4th century, sensed the tension between the parable and Matthew 20:16 (Chrysostom Homilies on Matthew 64.3-4). The excision of Matthew 20:16 from the parable goes part of the way to eliminating the powerful allegorising impulse with which interpreters of the parable have had to deal. An assessment of what is realistic in the parable and what is not will add additional reasons to resist an allegorising or even moralising interpretation.

\section{A social-scientific and realistic reading of the parable The Vineyard Labourers and realism}

How realistic is the parable? According to Snodgrass (2008:369), 'the picture the parable presents uses realistic but exaggerated features.' The realistic features in the parable are the hiring of workers from the market at a time of need, the wage paid, and the owner (who 'is probably reasonably well-off, but not so wealthy that he leaves oversight of his vineyard to agents') doing the hiring. Unrealistic in the parable, however, are the excessive number of hirings (why

\footnotetext{
5.The only exceptions here are the views of Crossan and Via. Crossan (1973:113-114 1974:35) delimits the parable to Matthew 20:1-13. According to him, Matthew 20:2 and 13 form a chiasm; because of Matthew's emphasis on a good-evil contrast he added Matthew 20:14-16. Via (1967:150; 1974:125) delimits the parable to Matthew 20:1-14a, arguing that the parable has as focus the grumbling workers, and not the goodness of the owner.
}

were the last hired not seen earlier and why could the owner not calculate his needs better?'), ${ }^{6}$ and the equal pay of all the labourers (see Snodgrass 2008:369).

Recent studies ${ }^{7}$ have shown that papyri from early Roman Egypt provide 'solid ancient comparanda on the practices and social realities which the sayings of Jesus and the parables presuppose' (Kloppenborg 2014b:2). ${ }^{8}$ Documentary papyri are important because they are nearly contemporary with Jesus' parables, and because they reflect the actual economic and social practices presupposed by the parables but often ignored as more elite writers. Moreover, the practices evidenced in early Roman Egypt cohere with practices that are later mentioned (albeit in much more lapidary and fragmentary way) in Rabbinic writings from Palestine in the third and following centuries.

The parable of the Vineyard Labourers presupposes most of the same practices as those imagined in the parable of the Tenants (Mark 12:1-12 and par; Gospel of Thomas 65). The latter parable has been the subject of an extensive study by Kloppenborg (2006:278-316), who made use of documentary papyri dating from $258 \mathrm{BCE}$ to the 4 th century CE). Several features of ancient viticulture are salient.

The parable firstly, takes for granted a system of land tenure in which most of the productive land was held by largescale (elite) owners. ${ }^{9}$ As many have indicated, beginning in the First Temple period and continuing in the Second, a pronounced shift in the patterns of land tenure took place, shifting from smallholders producing the Mediterranean triad of grain, grapes and olives for subsistence to large estates orientated to large-scale production and export crops (Oakman 2008:189). Documentary papyri show that the creation of large states in Palestine was in full swing in the Hellenistic period ${ }^{10}$ (see also Fiensy 1991:21-22). In cases at least, these large estates were converted to viticulture and dedicated to export crops. ${ }^{11}$ Literary sources also indicate the existence of substantial Herodian estates in the early

6.See also Funk, Hoover \& The Jesus Seminar (1993:225), who are also of the opinion that the parable 'exaggerates the actions of the vineyard owner.'

7.See, for example, Kloppenborg (2011:323-351; 2014a:287-306; 2014b:491-511 556-576; 577-599), Bazzana (2011:511-525, 2014:1-8) and Van Eck (in press a).

8.The Graeco-Egyptian papyri, and a few papyri preserved from the 'Arava, are contemporary with 1st-century Palestine and reflect similar non-elite social contemporary with. 1st-century Palestine and rectia strata and processes'. With 'due allowance made for legal and cultural differences understanding the realia which the parables presuppose' (Kloppenborg 2014a:289).

9.For papyrological evidence on elite owning large states, see P.Lond VII 1948; PSI VI 554; P.Köln III 144; P.CairZen II 59162, IV 59186; P.Fouad I 43; P. Hamb I 23 and P.Lau IV 166 (also see also Pliny Hist. nat. 17.171; Columella De re rustica 3.13, 5.3).

10.Apollonios, the finance minister (dioikētēs) of Ptolemy II Philadelphos, for example, owned several estates, including one somewhere in the Galilee (see PSI VI 554, P.Lond VII 1948). For evidence of his Egyptian estates, see, for example, PSI V 518, VI 554 and P.CairZen II 59173 and Rostovtzeff (1922).

11.Also Herzog (1994:85) claims that owners of large estates increased their tenure through foreclosures on loans, leading to hostile takeovers of peasant farms. When possible the land so annexed was converted into vineyards so it could produce possible the land so annexed was converted into vineyards so it could produce a product with a higher return than the mixed grains grown by subsistence peasan farmers.' There is plenty of evidence of the conversion of land into vineyards; see for example P.Lond II 483, VII 1948; BGU IV 1122, XII 2177; P.Mich 9229; P.Mil.Vog 69, VII 308; P.Cair.Masp I67097; P.Col.Zen II 7,; P.Flor II 134; P.Oxy IV 707; P.Ry 427, PSI VI 554, P.CairZen II 59162, IV 59816, and P.Koln III 144. As to Herzog's claim about the mechanism by which land was acquired, there is very little direct evidence, so Herzog's claims must remain suppositions. 
Roman period (see Josephus, Ant. 15.264; 17.305-307; Vita 33; 47; 115; 422; 429; Bell 1.403-405; 3.36; see also Fiensy 1991:55-57).

The shift from subsistence farming (polycropping) to monoculture, especially viticulture, had a profound effect on the structure and nature of labour. Viticulture was the most labour-intensive of agricultural pursuits, requiring more permanent workers than cereal and other agricultural production: Cato recommends 16 permanent workers to care for a 100 iugera (25.3 ha.) vineyard (De agricultura 11.1-13).

Vineyards, however, required large temporary labour inputs during the agricultural cycle for the clearing of brushwood, weeding, burning weeds, hoeing and pruning. ${ }^{12}$ The most demanding period for extra workers was the vintage period when pickers and treaders were needed in large numbers. Once ripe, grapes had to be picked quickly and could not be stored for long without rotting; extra workers thus were needed to tread and press the picked grapes within a few days after being harvested. The vintage period thus created an exceptional labour demand and, as documented papyri attest, it was normal to make use of day labourers to fill this seasonal large demand for labour. ${ }^{13}$ Rathbone (1981) estimates that for Cato's 100 iugera vineyard an additional 40 pickers would be needed, and in addition, workers to transport, sort, and press the vintage. ${ }^{14}$ This temporary labour hired in the market place, comprised probably of smallholders who needed to supplement their farm incomes and by unlanded labourers, perhaps displaced peasant farmers.

A second important aspect of viticulture in the 1st century attested by documented papyri is its association with wealth and the wealthy. Viticulture not only demanded high labour costs, but also required substantial capital input. ${ }^{15}$ A newly planted vineyard took four to five years to come into full production, which means that an owner would have to have other sources of income to rely on during the initial growth period. Owners also had to cope with bad weather that damaged crops, neglect, theft, the degradation of soil conditions, and the falling of prices. Only the wealthy thus could afford to engage in medium- and large-scale intensive,

12.For special and seasonal tasks related to viticulture, see P.Heid iil 326 ; P.Oxy X Xiv 1631, 1692; P.Col.Zen I 59103. II 79; IV59176, 59548, 59549 and P.Zen.Pestm 64. Also see a detailed list of specialised and seasonal tasks needed in vineyards in Kloppenborg (2006:578).

13. For evidence from documented papyri on the use of day labourers, see P.Lond VII 1957; P.Cair.Zen IV 59748, 59827 and P.Mich II 127 and I 200. Documented
papyri also abundantly attest to the payment of daily wages for workers (see list of papyri also abundantly attest to the payment of daily wages for workers (see list of
papyrological evidence in Kloppenborg 2006:579-580). See also Fiensy (1991:85papyrological evidence in Kloppenborg 2006:579-580). See also Fiensy (1991:85-
$90)$ and Malina and Rohrbaugh (2003:100-101) on the use of day labourers in viticulture.

14. Rathbone (1981:12-13) concludes: 'It would probably be an underestimate to assume the employment by the villa during the vintage of casual labourers to the value of 1,000 man-days.' See also Murray (2000:585-590) and Kloppenborg (2006:288-290)

15.Capital invest was needed inter alia for outlays for vine supports, the installation of irrigation, the erection of fences, the construction of a stone-built field tower for the storing of tools and facilities for pressing and storage, the construction of water Wheels, catch basins, storage tanks and a press, the excavation of a treac and the purchase or fron tools and draft animals (see also Cato, Agr. 11.2-13.2 Van Eck 2007). For a detailed list of an owner or lessor's expenses documented in papyri, see Kloppenborg (2006:560-561, 570). export-orientated viticulture. Yet vineyard owners prior to the 2nd century CE were not typically the old patricians, who regarded viticulture as too expensive and risky, despite Columella's attempts to persuade his peers of the value of vines. On the contrary, vineyard owners in the 1st century were the nouveau riche, imperial freedmen with disposable cash (Kloppenborg 2006:299-302). Although we have no direct evidence for Jewish Palestine as to the wealth of vineyard owners, the basic needs of high capitalisation, wage inputs, and the instability of yields and markets, imply that also only the middling wealthy were able to engage in intensive viticulture. In addition, the distribution and location of large winepresses along trunk roads leading to the coast indicates a strong orientation to export rather than purely local consumption (Frankel 1999:141; Kloppenborg 2006:302-303).

A final aspect of viticulture evoked by the parable is that of absenteeism. In fact that owner absenteeism was the norm in viticulture. ${ }^{16}$ Vineyards were both capital intensive, requiring investment from those with sufficient capital to sustain up to five years of care for a non-producing vineyard, and they required specialised agricultural expertise in the form of vinedressers. The former were typically wealthy sub-elites, and the latter were agricultural workers who may have doubled as managers (Purcell 1985; Kloppenborg 2006:295-303).

Owners were seldom involved in the day-to-day management of the vineyard, still less of the hiring and payment of temporary help. ${ }^{17}$ If an owner were to visit his or her vineyard, it would be either a surprise inspection, to ensure that the manager was protecting the owner's interests, or at harvest, not to direct or manage the details of the harvest, but to ensure that there was no pilferage and that the full extent of the harvest was realised to the owner's account. For other matters, the operation of the vineyard was left in the hands of slave labour ${ }^{18}$ supervised by a vilicus (Carlsen 1995), or day labourers supervised by a manager, or leased their vineyards to tenants ${ }^{19}$ who could properly care for their vineyards.

A papyrus letter from the Zenon archive illustrates this well: ${ }^{20}$

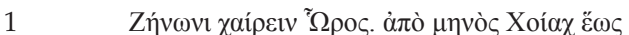

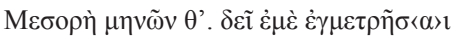
$\tau$

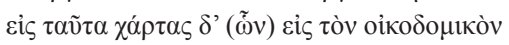

16.See Kloppenborg (2006:314-316) and the documents cited there

17.On estate management, see Carlsen (1995). Choi (2010:107) remarks that direct 'management [of estates] was infrequently employed in the case of large landholders. Instead, large landholders typically resided in urban centres, from whence instructions were issued concerning the management of their rural property. This is particularly true in the case of vineyard owners, for viticulture was not only labour-intensive, but also required specialized labour.'

18.See, for example, P.Col.Zen II 90 and P.Mich I 49.

19.See, for example, P.Col.Zen II 79; P.Ryl. IV 583; P.Köln III 144; BGU IV 1119, 1122 P.Lond. II 163; P.Harr. I 137; P.Oxy. IV 729; P.Flor. III 369; P.Ross.Georg. II 19; P.Oxy. XIV 1631, 1692; P.Oxy. XLVII 3354

20.Cited from Kloppenborg 2006:400-401 (n. 14). 


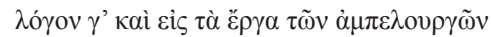

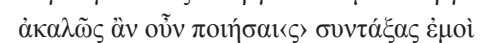

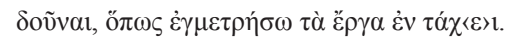

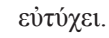

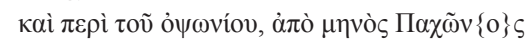

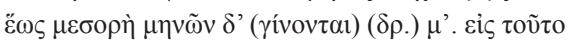

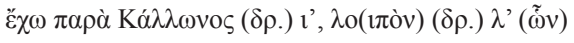
نं

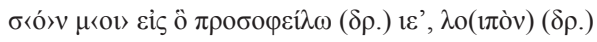
$1 \varepsilon ' . \kappa \alpha \lambda \tilde{\omega} \varsigma$

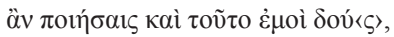

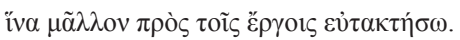
$\mathrm{L} \lambda \varsigma^{\prime}, \Theta \tilde{\omega} \theta \lambda$ '. ${ }^{\tau} \Omega \rho \circ \varsigma \chi \alpha \rho \tau \tilde{\omega} \nu$, ỏ $\omega v$ víov.

Horos to Zenon, greetings. From the month of Choiak until Mesore is nine months. I must apportion the work, and there are many things to be done. Now I will use four papyrus rolls on these things, three for the construction (5) account and one for the work of the vinedressers. Therefore please arrange to give me (more) so that I can apportion the work quickly. Farewell.

Now in regard to my monthly salary: from the months of Pachons (10) to Mesore is four months, making $40 \mathrm{dr}$. In payment I have received from Kallon $10 \mathrm{dr}$., leaving $30 \mathrm{dr}$. From this you should deduct the $15 \mathrm{dr}$. that I still owe (you). This leaves $15 \mathrm{dr}$. It would be good if you could give this to me so that I will be conscientious in regard to my job.

(15) Year 36, Thoth 30. Horos, regarding papyrus scrolls (and) (his monthly) salary. (P.CairZen. III 59317)

Zenon was the manager (oikovónos) of the many estates of Apollonios, the dioikētēs of Ptolemy II Philadelphos (285-246 BCE) but was not involved in the daily management of any of those estates. Horos, whose title is not given, but who functioned like Matthew's غ̇ $\pi$ í $\rho \circ \pi \circ \varsigma$, was responsible for the management of the vineyard, including the assigning of work to the vinedressers and the keeping of accounts that

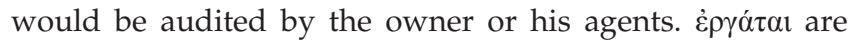
not mentioned, probably because of the date of the papyrus (Thoth 30 = November 23), well after the conclusion of the vintage period. Nevertheless, it would have been the manager, not the owner or his agents, who was responsible for directing the work of pruning and weeding from Choiak (late January) onward, and especially for the harvest (in Mesore $=$ September) ${ }^{21}$ Each of these tasks required the labour inputs not only from the vinedressers, who were often salaried employees or slaves, but also from hired day

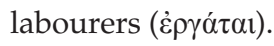

With the above in mind, how realistic is the Vineyard Labourers? From the above evidence from documented inscriptions and papyri, it is clear that the story begins in

21. Contrast Schottroff (1984:129): "il]t is an everyday occurrence for the owner of vineyard to hire workers in the marketplace.' Rightly Donahue (1988:79-80) and Carter (2000:395-396): 'The householder's act of going out early in the morning to hire day laborers for his vineyard is somewhat unusual. This is usually the manager's task.' See also Herzog (1994:86-87): '[l]f the householder does belong to the urban elite, why does he, not his steward, go to the agora to hire day laborers? Ordinarily, elites remained invisible, preferring to let their retainers do the visible work, such as hiring day laborers for the lowest wage possible'. an entirely recognisable vein: the harvest is approaching and a large (temporary) labour force is needed to bring in the vintage, which must be picked and processed quickly in order to prevent spoilage and theft.

The scenario in the parable involves two management

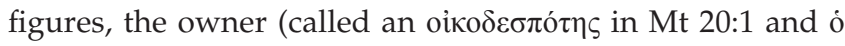

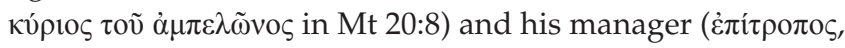

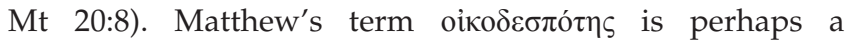
Matthaeanism: It is clearly redactional in Matthew 10:25 and

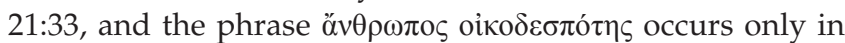
Matthaean parables (Mt 13:52; 20:1; 21:33), and in the latter two instances identifies the protagonist of the parable with

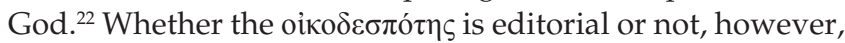
there are two odd features of the story: The active nature of the owner during the harvest, and the scenario of multiple hirings.

\section{A propos of the first point, Choi (2010) remarks:}

When the manager is introduced half-way through the parable (v. 8) ..., the owner's membership in the urban and not the rural population becomes clear. As a member of the urban population, both the owner's presence at and his participation in the activities of the vineyard would have struck the original audience as peculiar. (p. 116)

\section{She concludes:}

The parable's portrait of the vineyard owner, then, would have struck the original audience as peculiar in at least three ways. First, since landholders were typically absent, the mere presence of the owner was peculiar. Second, since the purpose of these visits was one of inspection, all of the owner's participation in the affairs of the vineyard was peculiar: his participation in the hiring of day labourers, the multiple trips to the agora, and his presence when the wages were paid, for these were the responsibilities of the manager. Third, since urban-rural interaction typically occurred in the urban domain, the presence of the owner in the parable is peculiar not only with respect to his status as the owner, but also as a member of the urban population who had travelled against the normal direction of movements and had engaged in urban-rural interaction in the rural domain. (Choi 2010:118)

The second odd feature of the story is the scenario of multiple hirings. But it seems pointless to argue whether this is a realistic detail or not. Presumably competent and experienced managers (and even owners) knew the size of the labour force that was required to bring in the vintage. Evidently the story does not imagine a labour shortage, since

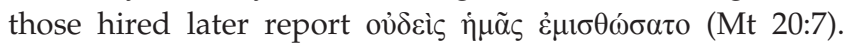
The multi-stage hiring scenario, though rather artificial, is essential to the telling of the parable. Without it there would be no story.

Although the presence of the owner, especially his involvement in hiring, is unusual, it is also essential to the

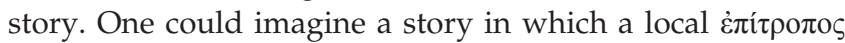

22. Matthew $10: 25^{\mathrm{k}} ; 13: 27^{\mathrm{s}}, 52^{\mathrm{s}} ; 20: 1^{\mathrm{s}}, 11^{\mathrm{s}} ; 21: 33^{\mathrm{R}} ; 24: 43$ (= Q). Three times Matthew

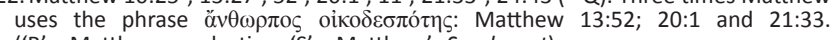
(' $R$ ' = Matthaean redaction; ' $S$ ' = Matthew's Sondergut). 
acted in the unusual way in which Matthew's owner acted and

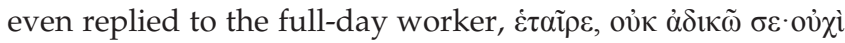

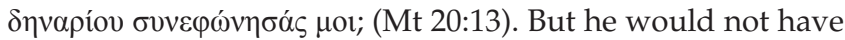

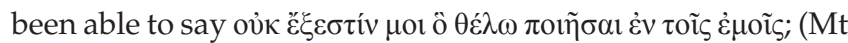
20:15), since the غ̇ $\pi$ í $\rho \circ \pi$ o had a fiduciary responsibility to act in the interests of his employer (or owner).

The parable, then, is a combination of verisimilitude and unusual features. This is in fact quite typical of many of the parables ascribed to Jesus, which proceed by telling a story that is realistic, if somewhat unusual, and that deliberately invokes certain cultural scripts or believes about the world. Then it challenges or problematises those scripts and beliefs through an unexpected narrative turn. Narrative realism is essential, for it is only by means of a realistic idiom that the he can be induced to identify with characters in the story before the 'trap' is sprung (Kloppenborg 2006:278). ${ }^{23}$

\section{What then is the point of the parable? \\ Reading the parable}

In the Vineyard Labourers the kingdom is compared with the actions of an owner, someone who owns a vineyard (Mt 20:1). The owner is not obviously, as many assume, a

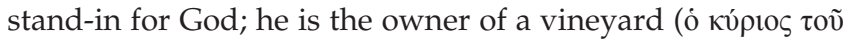
$\grave{\alpha} \mu \pi \varepsilon \lambda \tilde{\omega} v o \varsigma)$ as stated in Matthew 20:8. ${ }^{24}$ For the hearers, the parable starts with a shock. Firstly, as in the parables of the Lost Sheep, the Great Feast, and the Merchant, the kingdom is likened to a negatively-marked character (see Van Eck 2011a, 2013, in press b), someone not normally associated with the kingdom. The owner, when read in the context of available contemporary evidence, most probably was one of the wealthy sub-elites who owned large estates and converted the land to viticulture dedicated to the production of export crops. The owner was undoubtedly well off, since only the wealthy could afford to engage in medium- and large-scale intensive, export orientated viticulture, as we have pointed out. Yet there is a social taint to such persons, who were not the optimi and honestiores of ancient society, but the second

23.See also Hedrick 2004:43: Interpreting the parables requires knowledge of first-century Palestinian society, economics, politics, religion, and farming practices if they are to be understood in that context. Such knowledge of firstcentury practices evokes awareness of subtleties in the narrative missed by the heavy-handed searcher for theological ideas... Knowledge of the social world acts as a brake to the overeager imaginations of all who mine the parables for acts as a brake to the overeager imaginations of all who mine the parables for theological insights ... Readers unaware of such almost subliminal social values 'To understand the parable, it is necessary to know who appears in its social script'.

24.In Hultgren's view, the landowner 'is surely a metaphor for God (cf. the designation of him as ó kóplos ["the lord/Lord"] at 20:8). Jesus' parables typically speaks of kings, fathers, and masters as the major figures, and in each case the heare or reader makes the metaphorical connection. To do so is not to allegorise. To fail to do so, or to refuse to do so, is to tear the parables from their symbolic universe' (Hultgren 2000:36; emphasis added; see also Snodgrass 2008:373) Shillington (1997:87-101), on the other hand, opines that Jesus would have presumed that, when he told a parable about an owner and a vineyard the cultural repertoire (social universe, in Berger's terms) of his audience would have made the association between the vineyard and Israel and the owner and God. Both the Both Hultgren and Shillington allegorise the parable, interestingly using direct 'vinosite bases for their interpretations. Both seem to presume that Kúploৎ and "vineyard was in speak of either without invoking God and Israel. This view is based on Matthew's interpretation of the parable, which is already an allegorisation of the parable received in the tradition. tier of the newly wealthy. ${ }^{25}$ It is no doubt an exaggeration to suppose that the original audience of the parable would think that the owner was evil and a thief (see Malina 1981:84); but the owner was not obviously a positive figure either. We are not told how such persons acquired their land - perhaps through expropriation, or default on loans, or as gift estates from conquered lands or as simple purchase from failing farmers. Whichever the case, the new focus on monoculture, and viticulture in particular, had a significant and not altogether positive impact on the daily lives of the peasantry, with increased pressure on smallholders, an increasingly monetised form of exchange, ${ }^{26}$ and the vagaries of labour demand. For several reasons, therefore, the parable starts with a shock: How can the kingdom be likened to a dubious character such as an owner of a vineyard?

In hearing the parable, the hearer's initial shock most probably quickly turned into puzzlement. As documented papyri indicate, it was normal for landowners to function as absentees, leaving the operation of their vineyards in the hands of agents and managers. The owner in the parable, however, is not only present, but directly involved; he sets off to the marketplace ( $\dot{\alpha} \gamma o \rho \alpha ́$ ) early in the morning (six o'clock) to hire labourers. ${ }^{27}$ This was not normal practice, contrary to their normal experience, and must have puzzled the hearers of the parable, especially since the owner had the services of a manager..$^{28}$ Why not the manager, who later pays the workers on the instruction of the owner?

25.See also Klausner (1925:170-180): The owner is a 'man of property' and has a manager indicating his wealth, because a manager 'supervised the numerous servants of a great property while the wealthy owner living in the city or was absent travelling in pursuit of business' (Klausner 1925:18). Scott (1989:289) place the owner amongst the class of patrons, and Herzog (1994:85) also describes him as wealthy; he has a vineyard, and 'vineyards were most like [sic] owned by elites because they produce a crop that can be converted into luxury items (wine), monetized and exported.'

26.Linked to the concept of limited good was the peasants' perception of production and the mode of exchange. Peasant production was primarily for use rather than exchange (e.g., export), and evaluated the world of persons and things in terms of use, and not exchange. For peasants it was unacceptable to sell commodities at a profit; it was considered as 'unnatural'. Profitmaking was seen as evil and socially destructive, since it was perceived as 'a threat to the community and community balance' (Rohrbaugh 1993:33; see also Malina 1981:97; Van Eck 2011c)

27.Day labourers, though free, were among the most disadvantaged of ancient workers. While slaves represented a capital investment to be protected against los and peril, غ̇ $\gamma \gamma \alpha \dot{\alpha} \tau \alpha \iota$ were more 'disposable'. Varro counsels using free labour rather than slaves for especially heavy work (opera rustica maiora) and in areas where the land was unhealthy (De re rustica 1.17.2-3). Nevertheless, it is an exaggeration to treat all of these as belonging to a single class of 'expendables', as some have argued (see, e.g., Herzog 1994:88). Since the parable is set at harvest time, some of those hired were likely the landless (otherwise they would have harvested thei own crops; see Malina \& Rohrbaugh 2003:101) while others were smallholders hwn crops, see Malina \& Rohrbaugh 2003:101), while others were smallholders (2000:114) is thus not correct in arguing that labourers were available simply because they were the undesirables of society.

28.Interpreters of the parable differ on the question whether the action of the owner should be seen as normal or abnormal. Schottroff (2006:212), Linnemann (1980:82) and Levine and Myrick (2013:101) argue for the first position. According to Schottroff, the owner does the hiring himself because he appears not to be one of the great land owners who live in the cities, but, as in the case of the Prodigal (Lk 15:11b-32), lives on the farm. For Linnemann, the hiring by the owner is normal; what is abnormal are the several times he goes out. Levine and Myrick believe it is normal because the owner is a Jew, basing their argument on late rabbinical sources such as $m$. B.M. 7.1. This Mishnaic text, however, does not state that the hiring is done by the owner himself. Most scholars who see the hirin by the owner as abnormal base their opinion on the conviction that the owner should be neen a symal for should be seen as a symbol for God, and that the hiring is an act of grace (see, e.g. Oesterley 1936:107, 109; Kistemaker 1980:73). For Herzog (1994:84) the hiring is abnormal, with the motive of the owner being a later face to face exploitation (shaming) of the hired workers. Scott (1989:289, 294) also sees the action as abnormal, with the intention of the owner to set up patron-client relationships.
Bailey $(2008: 357,358)$ sees it as 'odd', motivated by the owner's compassion for the unemployed. 
While hiring by the owner was unusual, the hiring itself takes place in the normal manner. In deciding on the wage, the workers and the owner agree on a daily wage of one

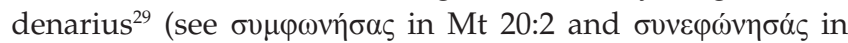
Mt 20:13), whereafter the workers are sent to work in the vineyard.

Scott $(1989: 289,294)$ suggests that the agreement to pay the workers establishes a patron-client relationship between the owner and the workers. One of the essential features of a patron-client relationship, however, was that it entailed a long-term social-interpersonal obligation, with moral obligations on both sides (see Saller 1982:41-78). ${ }^{30}$ This is not the case in the parable, at least at the beginning: The workers are hired for a day's work, and their obligation of the owner and his to them ceases at the end of the day.

At nine o'clock, the owner again sets off to the marketplace, and finds workers standing around not working ( $\dot{\varepsilon} \sigma \tau \tilde{\omega} \tau \alpha \varsigma$

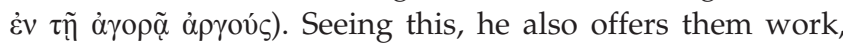

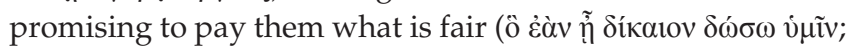
Mt 20:4). The same happens at twelve and three o'clock, and again workers are hired with the same agreement. With the

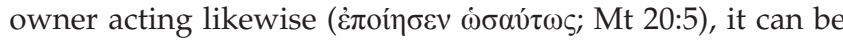
assumed that these workers are also promised to be paid what is fair (ô díkatov). Finally, at five o'clock, the owner again goes to the marketplace and finds workers, as was the case at nine o'clock, standing around ( $\dot{\varepsilon} \sigma \tau \tilde{\omega} \tau \alpha \varsigma_{;}$Mt 20:6). Asking them why they are still at the marketplace ( $\dot{\varepsilon} \sigma \tau \dot{\eta} \kappa \alpha \tau \varepsilon)$,

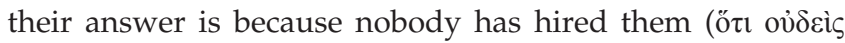

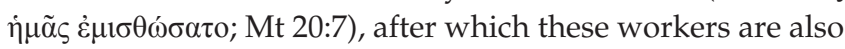
sent to work in the vineyard.

Before moving on to the final part of the parable, a few remarks are necessary. Firstly, although the hirings at twelve, three and five o'clock are described in a condensed manner, it can be assumed that the workers hired after six all were promised the same wage, that is, what is fair (ô घ̇òv

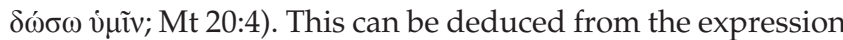

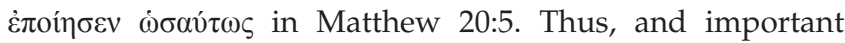
for the understanding of the parable, the early workers, as agreed upon, would be paid one denarius, and those who

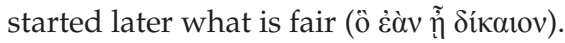

29. It is claimed ad nauseam that one denarius was the usual daily wage and exegetes frequently debate whether 1 denarius per day is 'a fair but not exorbitant payment'
(Levine \& Myrick 2013:102), or 'subsistence pay at the best' (Linnemann 1980:82) or (Levine \& Myrick 2013:102), or 'subsistence pay at the best' (Linnemann 1980:82) or a 'subsistence or lower-than-subsistence wage' (Herzog 1994:90). We have, however, little direct information on the wage structure from 1st-century Palestine. Evidence from Egypt ranges from 0.5 obols per day (i.e., 1/12 drachma; mid III BCE) to 3-4 obols per day (1/2-2/3 drachma; $78 \mathrm{CE}), 1$ drachma/day (II CE), with the majority of wages being less than 1 denarius or drachma. Moreover, what is needed is evidence of wage structures and contemporary prices of wheat in order to estimate the rea value of wages. Such a combination is lacking for most locales (including Palestine) and for most periods, except early Roman Egypt. Harris (2011:44-45) estimates HS 1.0-1.5 for an 'unskilled' labourer in Egypt in the 1st century. 'Let us say HS 1 [0.25 den.] in the first century. To meet expenses of HS 210 a year ... seems therefore to be just beyond the capacity of such a man ... Many inhabitants of Roman Egypt probably suffered to varying degrees from destitution, and a whole social class would have disappeared if it had not been for the casual labour of women and children'. The most important factor to consider is that according to Christian (2014, following Scheidel 1996:224) ancient authors are prone both to exaggerate and to give sums in round numbers. This means that audiences were likely to take such numbers as symbolic rather than as actual figures.

30.For the salient features of patronage and clientism, see Eisenstadt and Roniger (1980:42-77, 1984:48-49), Saller (1982), Moxnes (1991:241-268), Wallace-Hadri (1989:63-87), Malina (1996:143-147), Malina and Rohrbaugh (2003:388) and Neyrey (2005:465-492)
Secondly, some interpreters pejoratively interpret the standing $(\dot{\varepsilon} \sigma \tau \tilde{\omega} \tau \alpha \varsigma)$ of the workers at the marketplace as 'idling' or 'loitering' (being lazy), an attitude, they argue, that is confirmed by the owner's question directed at the 'five

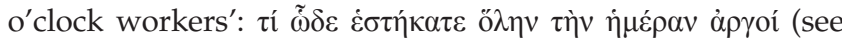
e.g., Borg 2006:182; Crossan 2012:96). This reads too much into the parable, as well as resting on a basic mistranslation of

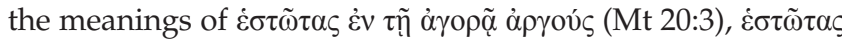

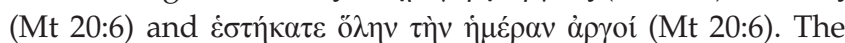

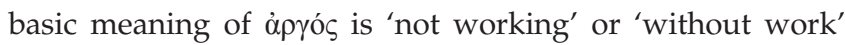
and lacks the pejorative sense of 'idling' or 'loitering'. The latter view anachronistically assumes an economy in which full employment is normal, whereas in fact the structure of the ancient agricultural economy inevitably resulted in chronic underemployment. ${ }^{31}$ The meaning 'not working' is also confirmed by the answer of the 'five o'clock workers': ö $\tau 1$ ov̉ $\delta \varepsilon$ $\dot{\eta} \mu \tilde{\alpha} \varsigma \dot{\varepsilon} \mu 1 \sigma \theta \dot{\omega} \sigma \alpha \tau \mathrm{o}$ (Mt 20:7). The workers hired after six o'clock were not loitering or lazy; they were there looking for work, hoping that someone would hire them. Moreover, it cannot be assumed with confidence that at the different hours the owner hired all the workers waiting at the marketplace to be hired, or that those hired later only showed up later (see Beare 1981:402). The parable does not provide enough information to make these conclusions. The parable, however, does state that those who were hired at five waited at the marketplace

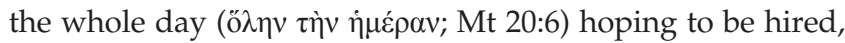
which probably implies that the owner had a choice on whom to hire at nine, twelve, three and five o'clock. As will be indicated below, this possibility is an important aspect in trying to get to a possible meaning of the parable.

The third remark, linked to the above, relates to the question of realism: Is the action of the owner, hiring extra workers at nine, twelve, three and five o'clock realistic? What motivated him to hire workers up to as late as five o'clock? For Hultgren (2000:37) the answer to these questions lies in the fact that the parable does not describe a real event; for Crossan (2012:97) it is because the owner was a cheapskate (trying to have as few workers possible to pay); and the well-known opinion of Herzog (1994:85-86) is that the owner deliberately wanted to exploit the workers by taking advantage of those who were looking for work to meet his harvesting needs by offering them work without a wage agreement. Jeremias (1972:136; see also Breech 1983:145), on the other hand, has made the suggestion that the parable should be read against the possibility that it was harvest time (close before the onset of the rainy season), which would make the many hirings understandable. ${ }^{32}$

31.See Erdkamp (1999) and Pleket (1987). See also P.Lond. Iil 1170v.45, 129 (259 CE), a monthly farm account which lists various workers under the heading $\lambda$ ó $\gamma_{0}$ $\dot{\varepsilon} \rho \gamma \alpha \tau \tilde{\omega} v \dot{\alpha} \rho \gamma \eta \sigma \alpha ́ v \tau \omega v$, which include workers who are in town, or ill, and who nonetheless are allowed wine. These workers appear to be attached to the farm,

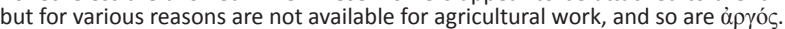

32.'The vintage and the pressing had to be finished before the onset of the rainy season' (Jeremias 1972:136). Bailey (2008:357) follows the suggestion of Jeremias, adding the possibility that the urgent hiring of the owner also could be because of the need to prune the vines in time. Derrett (1974:72) also sees the hirings taking the need to prune the vines in time. Derrett (1974:72) also sees the hirings taking place at harvest time, adding that the next day was the Sabbath, and therefore the urgency of the hirings. Linnemann (1980:82, in following Bultmann), on the other hand, is of the opinion that if the parable is placed with the harvest it ruins the parable: it mitigates the generosity of the owner because he then only shows
gratitude to those who came last who 'did not leave him in the lurch in a crucial situation.' 
It is at this point that the quest for a realistic scenario breaks down. The narrative outcome of the parable - equal payment for all - and the surprise it produces requires an artificial scenario of multiple hirings. ${ }^{33}$ To treat the parable's scenario as realistic entails having to suppose either that the manager was inexperienced and failed to estimate adequately the size of the crop and the amount of labour that the vintage would require, or that the first attempts to hire workers produced fewer than necessary, and therefore additional forays into the marketplace were required. But nothing in the parable suggests that either the owner or his manager was incompetent, and the exchanges between the owner and the workers that were hired later fail to indicate that there was a pressing reason to hire them. The suggestions of Crossan and Herzog ascribe bad faith to the owner where the parable offers no purchase for such views.

The workers hired in the middle of the day, is not only an essential part of the plot of the parable, but also the key to understand the payment of the workers by the manager. This becomes clear when the owner instructs his manager to call the workers and pay them in reverse order; a sequence that Hultgren (2000:38) sees as 'surprising'. Interpreters of the parable have speculated as to the reason of this sequence: According to Buttrick (2000:114), for example, it shows that the owner is both unjust and arrogant, or that he deliberately insults and shames the first workers by paying them last (Herzog 1994:91; see also Jeremias 1972:137; Ford 1997:117). These readings of the parable contradict the description of the owner in Matthew 20:15, namely that he is good (ö $\tau 1$ غ̇ $\gamma \grave{\omega}$

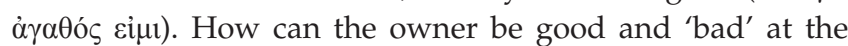
same time, especially since he hired workers up to as late as five o'clock?

The reverse order of payment does not correspond to any known practice; but it is clearly required narratively in order to create in the twelve-hour workers (and the hearer of the parable) the expectation of a greater payment. ${ }^{34}$ This is a literary artifice, nothing more. The result of this artifice, however, is to construct the owner as an example of patronage, and perhaps an unusual though hardly unique example of patronage.

Examples of this form of largesse are attested among managers dealing with dependent tenants. ${ }^{35}$ Cato warns against allowing a manager (vilicus) to extend credit to tenants or others in the debt of his owner, or to lend seed

\footnotetext{
33.Contra Snodgrass (2008:369), who argues that the workers hired in the middle of the day are not really necessary for the plot of the parable.

34.According to Malina and Rohrbaugh (2003:101), the workers are paid in reversed order because those who were hired later were clients of the owner, workers with whom he had a long-standing patron-client relationship. This they deduce from the fact that when the owner hires these workers no fixed wage is set, but rather

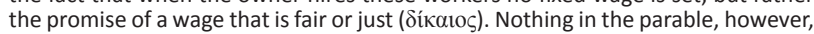
suggests that the later workers initially were clients.

35.See Foxhall (1990:103): 'In situations where part of a large landed property was run by a slave bailiff, he may have become an important agent in negotiating for the owner with tenants. As such the bailiff may have become a powerful patron figure in his own right to some small tenants; presumably not all landlords were figure in his own right to some small tenants; presumably not all landlords were
as conscientious as Pliny claims to have been in seeing to querelae rusticae. Such as conscientious as Pliny claims to have been in seeing to querelae rusticae. Such
estate managers formed the basis for patronage networks in Andalusia, and were the builders of the Mafia organization in nineteenth-century Sicily'.
}

grain, fodder, wine or oil (again, presumably to tenants or workers), and recommends that the vilicus not hire the same day labourer (operarius), hired servant (mercennarius) or cultivator (politor) for more than one day (De re rustica 5.3-4). Cato is patently concerned that the manager not become a patron to those in his hire for fear that the owner's interests will suffer. Yet the advice Cato gives is unworkable: Farms (and their managers) were dependent on a steady source of labour and had to cultivate reliable tenants, and others who could supply the labour and additional inputs that the farm required. The Roman agrarian economy functioned because of the integration of both producers (i.e., tenants and other workers) and owners into a 'single system of economic and social interdependence' (Van Dommelen 1993:177) and patronage was part of the essential 'glue' that held this system together.

In bad times, a peasant family could rely on general reciprocity from other kin and neighbours; but in more serious crises, intervention 'from above' - the landlord, the ruler, or some powerful defender was necessary. And although the landlord might represent him- or herself as acting in a disinterested fashion, in fact, the landlord needed reliable cultivators. So also the manager of an estate required cooperation and willing workers. Rathbone (1981) has shown how owners of farms in the Ager Cosanus (modern Tuscany) were dependent on casual labour to being in their grape and olive harvests. It was hardly any different in Jewish Palestine; landlords and their managers, and tenants and day labourers were necessarily interdependent.

Absentee landlords were not in a position to intervene through patronage in the lives of their dependent tenants. Garnsey and Woolf (1989:160-161) point out that Pliny, who seldom visited his extensive estates in Tuscany and the Po Valley, disqualified himself, through absenteeism, from being able to offer effective patronage to the country folk with whom he had economic dealings. Pliny's managers, might have offered relief in times of hardship. Pliny, however, complained repeatedly of the difficulties in securing reliable tenants, their constant demands on his time and patience, and of their falling into debt (Pliny, Ep 3.19; 5.14; 6.3; 7.30; $9.15,36,37 ; 10.8)$. Indebtedness and an owner's willingness either to extend the repayment period or to forego the debt entirely, had advantages: Indebtedness, and even more, debt forgiveness, created a social obligation which could be exploited to the landlord's advantage in other ways. Rowlandson (1996) points out that in a slightly later period:

Socially, metropolitan landlords could not lose from the relationship with their tenants: if the tenant kept out of debt, the landowners obtained a secure, and in the second century remarkably high, income from rents, with virtually no input on their part; while the tenants who fell into arrears were placed under a social obligation, which could be drawn upon to serve the landlord's interests in the locality in a variety of ways. (p. 275)

The issue in the parable under discussion is not debt, but financial hardship, as the later workers explain: 'No one 
has hired us'. While one might have expected a bailiff or manager to act in the way that the parable narrates as a way to exhibit his patronage and in order to secure loyal workers for the future, the parable depicts the owner - usually an absentee - as intervening, thus exhibiting his patronage. The owner of the vineyard thus is not just a good employer, as Jeremias would have it, paying the agreed wage to some, but also a patron, offering benefits beyond the strict norms of

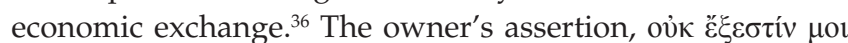

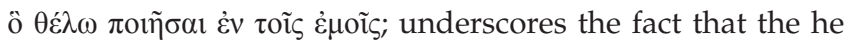
has stepped out of the role of the owner who thinks only in terms of a strict balance sheet, and into the role of a patron or benefactor whose actions create enduring and effective bonds with his clients, and who is entitled to benefit persons differentially.

In the description of the owner as being díkatos, the parable stands in the prophetic tradition of Isaiah and Jeremiah and Jesus himself. In the prophetic tradition being díkalos has the meaning of looking out for the orphan and the widow, that is, those who were the most vulnerable in society (see, e.g., Is LXX 1:17; Jr LXX 7:6; 22:3). In Matthew 5:6 and 10 being

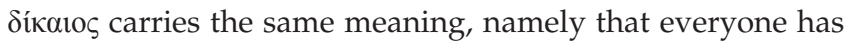
enough; Crossan (2010:14) describes díkalov as distributive justice.

While there is a temptation to turn Matthew 20:1-15 into an example story that is formulated to recommend certain behaviour, it is not entirely clear that this is the case. Other of Jesus' parables - notably, the Good Samaritan, Great Feast, and Dishonest Manager or Dishonoured Master - feature persons with whom the likely immediate audience of the parables would not identify and thus, in spite of Luke's efforts to turn them into example stories, in their original setting are better understood as stories that are meant to relate odd, even idiosyncratic behaviour. But it is idiosyncratic behaviour that ends in happy results: a traveller saved from death, the urban rabble fed, and a devious manager who escapes a beating or worse.

As such, these stories offer glimpses into odd characters that behaved in odd ways. There is no imperative attached: 'Go and do likewise'. But the cleverness of the story might in fact encourage one to do just that.

\section{A Parable of Jesus?}

The parable of the Vineyard Labourers has several markings of a Jesus parable. As in the case of the parables of the Lost Sheep (Lk 15:4-6), the Merchant (Mt 13:45-46), the Feast (Lk 14:16b-23) and the Samaritan (Lk 10:30-35), the kingdom is compared to the actions of a dubious character. The grumbling of those who started working first is echoed in the actions of the older brother in the Prodigal (Lk 15:11-32) and the shameless neighbour in the parable of the Friend at Midnight (Lk 11:5-8; see Van Eck

36. The scenario, of course, is quite artificial. To our knowledge, there are no instances in farm accounts of persons being paid for partial day labour. દ́pyó by the day, never less than a day. 2011b:1-14). Finally, the parable concurs with the meaning of the parable of the Lost Sheep, namely that the actions of someone (dubious) result in everybody having enough (see Van Eck 2011a:1-10).

\section{Acknowledgements Competing interests}

The authors declare that they have no financial or personal relationships which may have inappropriately influenced them in writing this article.

\section{Authors' contributions}

E.v.E. (University of Pretoria) and J.S.K. (University of Toronto) contributed equally to the writing of this article.

\section{References}

Bailey, K.E., 2008, Jesus through Middle Eastern eyes: Cultural studies in the gospels, IVP Academic, Downers Grove.

Ball, M., 2000, The radical stories of Jesus: Interpreting the parables today, Regent's Park College, Oxford.

Bazzana, G.B., 2011, 'Basileia and debt relief: The forgiveness of debts in the Lord's Prayer in the light of documentary papyri', The Catholic Biblical Quarterly 73 , 511-525.

Bazzana, G.B., 2014, 'Violence and human prayer to God in Q 11', HTS Teologiese Studies/Theological Studies 70(1), Art. \#2733, 8 pages. http://dx.doi.org/10.4102/ hts.v70i1.2733

Beare, F.W., 1981, The Gospel according to Matthew, Harper \& Row, San Francisco.

Blomberg, C.L., 2012, Interpreting the parables, 2nd edn., InterVarsity Press, Downers Grove.

Borg, M.J., 2006, Jesus: Uncovering the life, teachings, and relevance of a religious revolutionary, HarperCollins, New York.

Bornkamm, G., 1960, Jesus of Nazareth, Harper, New York.

Breech, J., 1983, The silence of Jesus: The authentic voice of the historical man, Doubleday, Toronto.

Bultmann, R., 1968, History of the synoptic tradition, transl. J. Marsh, Blackwell, Oxford. Buttrick, G.A., 1928, The parables of Jesus, Harper \& Row, New York.

Buttrick, D., 2000, Speaking in parables: A homiletical guide, Westminster John Knox Press, Louisville.

Carlsen, J., 1995, Vilici and Roman estate managers until $A D$ 284, L'Erma di Bretschneider, Roma. (Analecta Romana Instituti Danici. Supplementum, 24).

Carter, W., 2000, Matthew and the margins: A sociopolitical and religious reading, Orbis Books, Maryknoll.

Choi, A., 2010, 'Urban-rural relations and the economy of lower Galilee', Ph.D. dissertation, The Toronto School of Theology, University of Toronto.

Christian, M., 2014, 'Numbers, sums and prices: Monetary thinking in Luke-Acts', paper presented at the conference Luke on Jesus, Paul, and earliest Christianity: What did he really know? Fourth International Symposium of the Leuven Centre for the Study of the Gospels, Leuven, 10-12 December 2014.

Cowan, D., 2007, Economic parables: The monetary teachings of Jesus Christ, Paternoster Publications, Colorado Springs.

Crossan, J.D., 1973, In parables: The challenge of the historical Jesus, Harper \& Row, New York.

Crossan, J.D., 1974, 'The servant parables of Jesus', Semeia 1, 17-62.

Crossan, J.D., 2010, The greatest prayer: Rediscovering the revolutionary message of the Lord's Prayer, HarperOne, New York.

Crossan, J.D., 2012, The power of parable: How fiction by Jesus became fiction about Jesus, SPCK, London.

Culbertson, P.L., 1988, 'Reclaiming the Matthean vineyard parables', Encounter 49, 257-283.

Davies, W.D. \& Allison, D.C., 1997, Matthew 19-28, vol. 3, T\&T Clark, Edinburgh. (International Critical Commentary Series.)

Derrett, J.D.M., 1974, 'Workers in the vineyard: A parable of Jesus', Journal of Jewish Studies 25(1), 64-91.

De Ru, G., 1966, 'Conception of reward in the teaching of Jesus', Novum Testamentum 8, 202-222. http://dx.doi.org/10.2307/1559991

Dodd, C.H., 1961, The parables of the kingdom, Charles Scribner's Sons, New York.

Donahue, J.R., 1988, The gospel in parable: Metaphor, narrative and theology in the Synoptic gospels, Fortress Press, Philadelphia.

Drury, J., 1985, The parables in the gospels: History and allegory, Crossroad, New York. 
Eisenstadt, S.N. \& Roniger, L., 1980, 'Patron-client relations as a model of structuring social exchange', Comparative studies in Society and History 22, 42-77. http:// social exchange, Comparative studies in
dx.doi.org/10.1017/S0010417500009154

Eisenstadt, S.N. \& Roniger, L., 1984, Patrons, clients and friends: Interpersonal relations and the structure of trust in society, Cambridge University Press, Cambridge. http://dx.doi.org/10.1017/СВ09780511557743

Elliott, J.H., 1992, 'Matthew 20:1-15: A parable of invidious comparison and evil eye accusation', Biblical Theology Bulletin 22, 52-65. http://dx.doi. org/10.1177/014610799202200203

Erdkamp, P., 1999, 'Agriculture, underemployment, and the cost of rural labour in the Roman world', Classical Quarterly 49(2), 556-572. http://dx.doi.org/10.1093/ $\mathrm{cq} / 49.2 .556$

Fiensy, D., 1991, The social history of Palestine in the Herodian period: The land is mine, Edwin Mellen Press, New York.

Fisher, N.F., 1990, The parables of Jesus: Glimpses of God's reign, Crossroad, New York.

Ford, R.Q., 1997, The parables of Jesus: Recovering the art of listening, Fortress Press, Minneapolis.

Foxhall, L., 1990, 'The dependent tenant: Land leasing and labour in Italy and Greece', Journal of Roman Studies 80, 97-114. http://dx.doi.org/10.2307/300282

Frankel, R., 1999, Wine and oil production in antiquity in Israel and other Mediterranean countries, Sheffield Academic Press, Sheffield. (JSOT/ASOR Monographs, 10).

Funk, R.W., Hoover, R.W. \& The Jesus Seminar, 1993, The five gospels: The search for the authentic words of Jesus, Macmillan, New York.

Garnsey, P. \& Woolf, G., 1989, 'Patronage of the rural poor in the Roman world', in A. Wallace-Hadrill (ed.), Patronage in ancient society, pp. 153-170, Routledge, London/New York.

Hagner, D.A., 1995, Matthew 14-18, Word Books, Dallas. (World Biblical Commentary, 33B)

Harris, W.V., 2011, Rome's imperial economy: Twelve essays, Oxford University Press, Oxford. http://dx.doi.org/10.1093/acprof:osobl/9780199595167.001.0001

Hedrick, C.W., 2004, Many things in parables: Jesus and his modern critics, Westminste John Knox Press, London.

Herzog, W.R., 1994, Parables as subversive speech: Jesus as pedagogue of the oppressed, Westminster, Louisville.

Hultgren, A.J., 2000, The Parables of Jesus: A commentary, Wm. B. Eerdmans, Grand Rapids.

Hunter, A.M., 1976, Interpreting the parables, SCM, London.

Jeremias, J., 1972, The parables of Jesus, SCM, London.

Jones, I.H., 1995, The Matthean parables: A literary and historical commentary, E.J. Brill, Leiden. (Supplements to Novum Testamentum, LXXX).

Jülicher, A., 1910, Die Gleichnisreden Jesu, Mohr Siebeck, Tübingen.

Kistemaker, S.J., 1980, The Parables: Understanding the stories Jesus told, Baker Books, Grand Rapids.

Klausner, J., 1925, Jesus of Nazareth His life, times and teaching, transl. H. Danby, Macmillan, New York.

Kloppenborg, J.S., 2006, The Tenants in the vineyard: Ideology, economics, and agrarian conflict in Jewish Palestine, Mohr Siebeck, Tübingen. (Wissenschaftliche Untersuchungen zum Neuen Testament, 195).

Kloppenborg, J.S., 2011, 'The representation of violence in Synoptic parables, in $\mathrm{E}-\mathrm{M}$. Becker \& A. Runesson (eds.), Mark and Matthew I. Comparative readings: Understanding the earliest gospels in their first-century settings, pp. 323-351, Mohr Siebeck, Tübingen.

Kloppenborg, J.S., 2014a, 'The Parable of the burglar in Q: Insights from papyrology' in D.T. Roth, R. Zimmermann \& M. Labahn (eds.), Metaphor, narrative, and parables in Q, pp. 287-306, Mohr Siebeck, Tübingen.

Kloppenborg, J.S., 2014b, Synoptic problems: Collected essays, Mohr Siebeck, Tübingen. (Wissenschaftliche Untersuchungen zum Neuen Testament, 329).

Lambrecht, J., 1992, Out of the treasure: The parables in the gospel of Matthew, Peeters Press, Louvain. (Louvain Theological \& Pastoral Monographs, 10).

Lenski, G.E., 1966, Power and privilege: A theory of social stratification, McGraw-Hill, New York.

Levine, A-J., 2014, ' 4 teachings from Jesus that everybody gets wrong', in Belief Blog viewed 22 September 2014, from http://religion.blogs.cnn.com/2014/09/21/ four-teachings-from-jesus-that-everybody-gets-wrong/

Levine, A-J. \& Myrick, C.S., 2013, 'Standard and poor: The economic index of the parables' in R.B. Stewart (ed.), The Message of Jesus: John Dominic Crossan and Ben Witherington III in dialogue, pp. 95-115, Fortress Press, Minneapolis.

Linnemann, E., 1980, Parables of Jesus: Introduction and exposition, 5th edn., transl. J. Sturdy, SPCK, London.

Malina, B.J., 1981, The New Testament world: Insights from cultural anthropology, Westminster John Knox Press, Louisville.

Malina, B.J., 1996, The social world of Jesus and the gospels, Routledge, London.

Malina, B.J. \& Rohrbaugh, R.L., 2003, Social science commentary on the Synoptic gospels, 2nd edn., Fortress Press, Minneapolis.

Moxnes, H., 1991, 'Patron-client relations and the new community in Luke-Acts', in J.H. Neyrey (ed.), The social world of Luke-Acts: Models for interpretation, pp. 241-268, Hendrickson, Peabody.
Murray, M.A., 2000, 'Viticulture and wine production', in P.T. Nicholson \& I. Shaw (eds.), Ancient Egyptian materials and technology, Cambridge University Press, (eds.), Ancient

Neyrey, J.H., 2005, 'God, benefactor and patron: The major cultural model for interpreting the deity in Greco-Roman antiquity', Journal for the Study of the New Testament 27(4), 465-492. http://dx.doi.org/10.1177/ $0142064 \times 05055749$

Oakman, D.E., 1986, Jesus and the economic questions of his day, Edwin Mellen Press, Lewiston. (Studies in the Bible and Early Christianity, 8).

Oakman, D.E., 2008, Jesus and the peasants, Cascade Books, Eugene. (Matrix: The Bible in Mediterranean context, 4).

Oesterley, W.O.E., 1936, The gospel parables in the light of their Jewish background, SPCK, London.

Patte, D., 1990, 'Bringing out of the gospel-treasure what is new and what is old: Two parables in Matthew 18-23', Biblical Quarterly 10, 79-108.

Perrin, N., 1967, Rediscovering the teaching of Jesus, Harper \& Row, New York.

Pleket, H.W., 1987, 'Labor and unemployment in the Roman Empire: Some preliminary remarks', in W. Ingomar (ed.), Soziale Randgruppen und Antike Sozialpolitik, pp. 267-276, Leykam, Gräz.

Purcell, N., 1985, 'Wine and wealth in ancient Italy', Journal of Roman Studies 75, 1-19. http://dx.doi.org/10.2307/300648

Rathbone, D., 1981, 'The development of agriculture in the "Ager Cosanus" during the Roman Republic: Problems of evidence and interpretation', Journal of Roman Studies 71, 14-23. http://dx.doi.org/10.2307/299493

Rohrbaugh, R.L., 1993, 'A peasant reading of the talents/pounds: A text of terror', Biblical Theology Bulletin 23, 32-39. http://dx.doi.org/10.1177/ terror', Biblical Theo

Rostovtzeff, M.I., 1922, A large estate in Egypt in the third century B.C.: A study in economic history, University of Wisconsin, Madison. (University of Wisconsin Studies in the Social Sciences and History, 6).

Rowlandson, J., 1996, Landowners and tenants in Roman Egypt: The social relations of agriculture in the Oxyrhynchite nome, Clarendon Press, Oxford and New York. (Oxford classical monographs).

Saller, R.P., 1982, Personal patronage under the early empire, Cambridge University Press, Cambridge. http://dx.doi.org/10.1017/СBO9780511583612

Scheidel, W., 1996, 'Finances, figures and fiction', Classical Quarterly 46(1), 222-238. http://dx.doi.org/10.1093/cq/46.1.222

Schottroff, L., 1984, 'Human solidarity and the goodness of God: The parable of the workers in the vineyard', in W. Schottroff \& W. Stegemann (eds.), God of the Lowly, pp. 129-147, Orbis Books, Maryknoll.

Schottroff, L., 2006, The parables of Jesus, transl. L.M. Maloney, Fortress Press, Minneapolis.

Scott, B.B., 1989, Hear then the parable: A commentary on the parables of Jesus, Fortress Press, Minneapolis.

Scott, B.B., 2007, 'The reappearance of parables', in E.F. Beutner (ed.), Listening to the parables of Jesus, pp. 95-119, Polebridge Press, Santa Rosa. (Jesus Seminar Guides, 2).

Shillington, V.G., 1997, 'Saving life and keeping Sabbath (Matthew 20:1b-15)', in V.G. Shillington (ed.), Jesus and his parables: Interpreting the parables of Jesus today, pp. 87-101, T\&T Clark, Edinburgh.

Snodgrass, K.R., 2008, Stories with intent: A comprehensive guide to the parables of Jesus, William B. Eerdmans, Grand Rapids.

Stein, R.H., 1981, An introduction to the parables of Jesus, The Westminster Press, Philadelphia.

Stiller, B.C., 2005, Preaching parables to postmoderns, Fortress Press, Minneapolis. (Fortress Resources for Preaching).

Stern, F., 2006, A rabbi looks at Jesus' parables, Rowman \& Littlefield, Oxford.

Tevel, J.M., 1992, 'The labourers in the vineyard: The exegesis of Matthew 20, 1-7 in the early church', Vigiliae Christianae 46(4), 356-380. http://dx.doi. org/10.1163/157007292X00179

Trench, R.C., 1877, Notes on the parables of our Lord, Macmillan, London.

Van Dommelen, P., 1993, 'Roman peasants and rural organization in central Italy: An archaeological perspective', in E. Scott (ed.), Theoretical Roman archaeology: First conference proceedings, pp. 167-186, Aldershot \& Brookfield, archaeology
Avebury.

Van Eck, E., 2007, 'The tenants in the vineyard (GThom 65/Mark 12:1-12): A realistic and social-scientific reading', HTS Teologiese Studies / Theological Studies 63(3), Art. 233, 909-936. http://dx.doi.org/10.4102/hts.v63i3.233

Van Eck, E., 2011a, 'In the kingdom everybody has enough - A social-scientific and realistic reading of the parable of the lost sheep, (Lk 15:4-6)', HTS Teologiese Studies/Theological Studies 67(3), Art. \#1067, 10 pages.

Van Eck, E., 2011b, 'When neighbours are not neighbours: A social-scientific reading of the parable of the friend at midnight (Lk 11:5-8)', HTS Teologiese Studies/ Theological Studies 67(1), Art. \#788, 14 pages. http://dx.doi.org/10.4102/hts. v67i1.788

Van Eck, E., 2011c, 'Do not question my honour: A social-scientific reading of the parable of the minas (Lk 19:12b-24, 27)', HTS Teologiese Studies / Theological Studies 67(3), Art. 977, 11 pages.

Van Eck, E., 2013, 'When patrons are patrons: A social-scientific and realistic reading of the parable of the Feast (Lk 14:16b-23)', HTS Teologiese Studies/ Theologica Studies 69(1), Art. \#1375, 14 pages. http://dx.doi.org/10.4102/hts.v69i1.1375 
Van Eck, E. (in press a), 'Honour and debt release in the parable of the Unmerciful Servant (Mt 18:23-33): A social-scientific and realistic reading', HTS Teologiese Studies/Theological Studies 70.
Stritis

Van Eck, E. (in press b), 'When an outsider becomes an insider: A social-scientific and realistic reading of the Merchant (Mt 13:45-46).

Vearncombe, E., 2010. 'Redistribution and reciprocity: A socio-economic interpretation of the parable of the Labourers in the Vineyard (Matthew 20.1-15)', Journal for the Study of the Historical Jesus 8(3), 199-236. http://dx.doi.org/10.1163/ $174551911 \times 571067$

Verhoefen, P., 2007, 'The first will be first: The labourers in the vineyard', in E.F. Beutner (ed.), Listening to the parables of Jesus, pp. 41-50, Polebridge Press, Santa Rosa. (Jesus Seminar Guides, 2).
Via, D.O., 1967, The parables: Their literary and existential dimension, Fortress Press, Philadelphia.

Via, D.O., 1974, 'Parable and example story: A literary-structural approach', Semeia 1, 105-133.

Wailes, S.L., 1987, Medieval allegories of Jesus' parables, University of California Press, Berkeley.

Wallace-Hadrill, A., 1989, 'Patronage in Roman society: From Republic to Empire', in A. Wallace-Hadrill (ed.), Patronage in ancient society, pp. 63-87, Routledge, New York.

Young, B.H., 1998, The parables: Jewish tradition and Christian interpretation, Hendrickson Publishers, Peabody. 